\title{
Comparative Effectiveness of Different Growth Media on Growth, Biomass and Morphology Features of Kinnow Mandarin Seedling
}

Taqi Raza ${ }^{1}$, Zurriat Hasnain Kazmi ${ }^{1}$, Muhammad Arshad Ullah ${ }^{3 *}$, Iqra Kanwal ${ }^{2}$, Shakeel Imran ${ }^{2}$, Rizwan Ahmad $^{3}$ and Syed Ishtiaq Hyder ${ }^{3}$

${ }^{1}$ University of Agriculture Faisalabad Sub Campus, Burewala, Pakistan

${ }^{2}$ University of Agriculture Faisalabad, Pakistan

${ }^{3}$ National Agricultural Research Center, Islamabad, Pakistan

Correspondence should be addressed to Muhammad Arshad Ullah, arshadullah1965@gmail.com

Received: February 13, 2019; Accepted: March 10, 2020; Published: March 17, 2020

\begin{abstract}
$\underline{\text { ABSTRACT }}$
An experiment was conducted at the University of Agriculture, Sub-campus Burewala Vehari during spring 2018 to investigate the most effective growth media for the growth of kinnow Mandarin seedlings along with highest potential of root, shoots, branches and leaves growth. The growing media is crucial for better plant growth and development. Seeds of Kinnow Mandarin were sown in twelve (12) different composite media (made from different proportions of peat moss, coco coir, compost, baggase, and soil) in CRD with three repeats. Data regarding germination of kinnow seeds and seedling quality parameters (Fresh weight, dry weight, seedling length, root shoot ratio, dry matter contents) were recorded during the experiment. The results proved that the peat moss was the most efficient among all the other growing media for producing the maximum number of leaves, shoot length, root length and seedling length while, compost was found to be a most effective medium for maximum seed germination. The composition in 1:1 of baggase + peat moss was most prominent to produce leaves with larger surface areas. Therefore, peat moss is an effective growth media among other growing media for Kinnow production.
\end{abstract}

\section{KEYWORDS}

Growth medium; Kinnow mandarin seedling

\section{INTRODUCTION}

Citrus has been cultivating all around the globe with tropical and subtropical climatic conditions, its cultivation has globally flourished due to its fruit and ornamental value. Citrus has also led the position among the fruits of Pakistan in which world fresh citrus production is 20\% [1]. In Pakistan during 2015-16, citrus was cultivated over an area of 206,569 hectares and the production remained 2.5 million tons [2]. Pakistan is on $12^{\text {th }}$ position in world in kinnow production. However, Kinnow fruit vigour is losing in Pakistan due to diseases attack, poor quality, low yield and lack of compatibility with seedless Kinnow. 
Kinnow Mandarin is the most adaptable variety among all citrus cultivars in the climate of Punjab province which is the major $(>95 \%)$ producer of citrus fruit [1]. The mandarin orange (Citrus reticulata L.) also known as mandarin, is a small tree with fruit resembling oranges. Citrus reticulata belongs to the Rutaceae family. Kinnow tree is more drought-tolerant can be grown in tropical and subtropical areas. High yield mandarin hybrids were cultivated extensively in the wider region of Pakistan and India. It is a hybrid of two citrus cultivars "King" (Citrus nobilis) $\times$ willow leaf (Citrus deliciosa) [3]. The major markets of Pakistani kinnow are mostly $2.6 \%$ of total kinnow exports from the developed country [4].

Growing media has a direct relation and effect on the growth parameters e.g. germination, development, and functional rooting system. A growing media with good composition provides sufficient anchorage or support to the plants, serves as reservoir for nutrients and water, allow oxygen diffusion to the roots and permit gaseous exchange between the roots and atmosphere outside the root substrate $[5,6]$. Seedling growth parameters significantly influenced by growing media under nursery [7]. The quality of seedlings obtained from a nursery influences re-establishment in the field and the eventual productivity of an orchard [8] for the growth and development of plants used natural growing media soil. Soil composition must be affected on plant growth, in which different types of soils are present. Sandy soil has the largest particles among the different soil types. The particles have huge spaces between drain, it can't hold on to water drained out due to its dry gritty to the touch. Clay soil with a large amount of clay is heavy and does not drain well because of high compaction between soil particles. Silty soil is powdery with high fertility. Unfortunately, soils with high silt can become waterlogged very easily. Therefore, these types of soils are not good for the better growth of the plants [9]. Therefore, use of different types of growth media is necessary for the best production and better quality of yield. Growth media is a nutritive substance that facilitates better plant growth. A perfect growth media contains optimum organic matter, porosity, aeration and cation exchange capacity. The range of growing media constituents used includes peat, wood fiber, coir pith, bark, composted material i.e. green waste, and bark. Mineral constituents like perlite, pumice, clay, and vermiculite have also used. Growing media has often formulated from a blend of such materials usually enriched with fertilizer. Plant species differ considerably in their need for water and nutrients. Growth media constituents are bark, coir pith, green compost, white peat, perlite, rice hulls, etc. [10]. Growing media are an integral part of most horticultural production systems.

Coir is obtained by mechanical processing of husks of coconuts. Similarly, coco coir is an agricultural by-product obtained after the extraction of fiber from the coconut husk. Coco coir is considered as a growing medium component with acceptable $\mathrm{pH}, \mathrm{EC}$ and other chemical attributes [5]. This material has good wet ability characteristics and is often mixed with other constituents in mixes for sowing propagation and potting. Green compost increases humic acid content, cation exchange capacity and water-soluble carbohydrates. These residual materials are decomposed by microorganisms under controlled conditions. White peat weakly to moderately decomposed and taken from the upper and younger layers of peat land. It has a visible plant structure and a yellowish-brown to dark brown color.

As the healthy seedlings are responsible for the best production of crops so they demand great attention. Different media are used to grow seedlings, as a media is the base of the efficient production of Horticulture seedlings in nurseries [11]. Many horticultural crops have been grown using soilless substrates in the container, including organic materials, such as peat moss. Peat is collected from wetland, marshes and bogs, which are often fragile ecosystem of ecological and archeological value 
[12] as peat moss has appropriate physical properties such as density and high total porosity and its high nutrient exchange capacity is considered as one of the main substrate component for seedling production in containers $[13,14]$. However, it is quite expensive to use peat moss as growing media for seedling production but still highly demanded around the globe.

\section{MATERIALS AND METHODS}

The experiment was conducted at UAF sub-campus Burewala-Vehari during spring 2018. The main objective was to determine the best growing media for the better growth, biomass and morphology features of Kinnow Mandarin seedling. The experiment consists of twelve treatments in different combinations with three repeats using CRD. Round shape soft black plastic pots with dimensions of $11 \mathrm{~cm}$ in height, $9 \mathrm{~cm}$ in length with a diameter of 10 inches were used for seed germination. Growing media peat moss, compost, coco-coir, baggas and normal soil was obtained from Lath house of UAF Sub-campus Burewala-Vehari. The media were sterilized using locally manufactured unit for steam sterilization (Mistquay International, Pakistan) at $80^{\circ} \mathrm{C}-90^{\circ} \mathrm{C}$ for 25 minutes at 15 psi following with certain modifications. The temperature and pressure conditions were optimized since most of the fungi, bacteria, insects, nematodes and weed seeds are killed up to $70^{\circ} \mathrm{C}-80^{\circ} \mathrm{C}$ [15]. The media were immediately cooled down and filled in transparent plastic pots. Each pot was filled with media up to $3 / 4^{\text {th }}$ of their total height leaving $1 / 4^{\text {th }}$ area empty. Total six seeds were sown in each pot in a square grid manner having plant to plant distance of $1 \mathrm{~cm}$. Seeds of kinnow mandarin were sown by hand at $1 \mathrm{~cm}$ depth. Establishing an irrigation of $30 \mathrm{ml}$ was applied immediately after seed sowing. Spray bottles having capacity $1000 \mathrm{ml}$ for irrigation purpose were used. Data on all seedling growth parameters were measured after 45 days of sowing. Twelve (12) different composite media were formulated by mixing growing media according to experimental treatments (Table 1).

\begin{tabular}{|c|c|}
\hline Treatments & Details \\
\hline $\mathrm{T}_{1}$ & 1 part peat moss +1 part coco-coir \\
\hline $\mathrm{T}_{2}$ & 1 part peat moss +1 part compost \\
\hline $\mathrm{T}_{3}$ & 1 part compost +1 part coco-coir \\
\hline $\mathrm{T}_{4}$ & 1 part bhaggas +1 part compost \\
\hline $\mathrm{T}_{5}$ & 1 part bhaggas + 1part soil \\
\hline $\mathrm{T}_{6}$ & 1 part bhaggas +1 part peat moss \\
\hline $\mathrm{T}_{7}$ & 1 part coco-coir +1 part Bhaggas \\
\hline $\mathrm{T}_{8}$ & Bhaggas \\
\hline $\mathrm{T}_{9}$ & Soil \\
\hline $\mathrm{T}_{10}$ & Coco-coir \\
\hline $\mathrm{T}_{11}$ & Compost \\
\hline $\mathrm{T}_{12}$ & Peat moss \\
\hline
\end{tabular}

Table 1: Treatment details.

\section{RESULTS AND DISCUSSION}

After forty five (45) days of sowing, comparative effectiveness of different growth media on growth, biomass and morphology features of Kinnow Mandarin seedling were measured. Most of the parameters were recorded manually from each pot e.g. Number of leaves and seed germination. Data showed that all the parameters were significantly influenced by media composition. Significant differences were observed between treatment means for the seed germination and the number of leaves per plant (Figure $1 \&$ Figure 2). Data regarding the seed germination indicated that the germination of seed significantly affected by the composition of growth media.

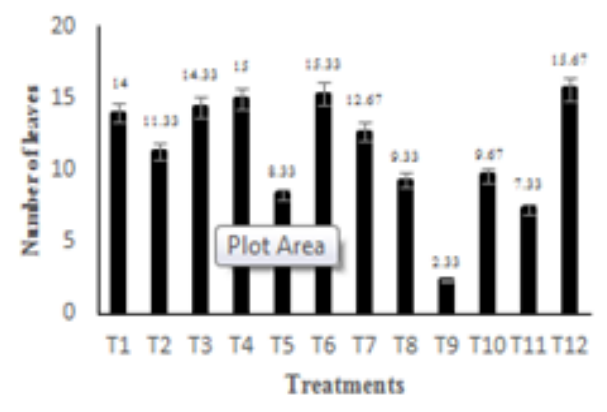


Figure 1: Effect growth media on number of leaves.

Significant differences are at $\mathrm{P}<0.05$.

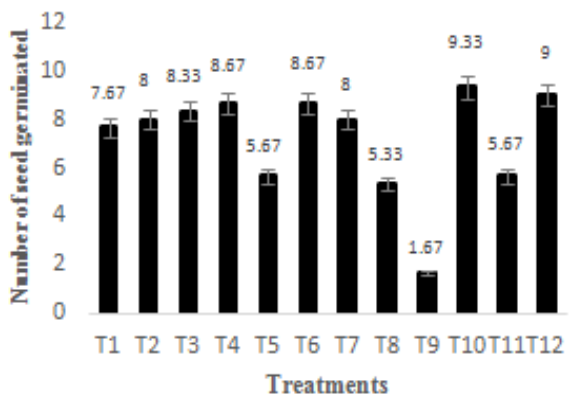

Figure 2: Effect growth media on number of germinated seeds. Significant differences are at $\mathrm{P}<0.05$.

Significant differences were observed among the treatment means of seed germination per pot (Figure 1). Among all treatments, the maximum number (9.333) of seed germination was observed in T10 (Coco-coir) as the coco coir have the good physical properties having water and nutrient holding capacity support the germination of Kinnow Mandarin seeds [16]. However, the minimum number of seeds germination (1.6667) was observed in treatment $\mathrm{T}_{9}$ (Soil) because the simple soil have less growth supportive properties as compared to other treatments. Treatment $\mathrm{T}_{6}(1$ part bhaggas +1 part peat moss) and $\mathrm{T}_{4}$ (1 part bhaggas +1 part compost) also performed very well to improve the seed germination but lower than the treatments $\mathrm{T}_{10}$ (Coco-coir) and $\mathrm{T}_{12}$ (Peat moss). Graphical representation shows that growing media significantly influences the growth and development of Kinnow mandarin seedling. Significant treatment difference among the treatments were observed regarding to seedling growth and development characters. Regarding the number of leaves, the maximum number of leaves (15.66) was observed in $T_{12}$ (Peat moss), followed by the treatment $T_{6}(15.333)$. But the minimum numbers of leaves (2.33) were observed in the treatment $\mathrm{T}_{9}$ (Soil). Peat moss widely used in the industry of horticulture especially for nursery development because it properly provides the aeration as well as drainage. It also hold and retain the required amount of water and applied nutrients and plant easily uptake when it as needed [6]. Figure 3 indicates that the behavior of root, shoot and seedling length severely affected by the composition of the growth media. Significant differences were observed between treatments mean of the root, shoot, and seedling per plant. Among all treatments, the maximum shoot length (6.8667 $\mathrm{cm})$ and seedling length $(6.8333 \mathrm{~cm})$ was observed in $T_{12}$ (Peat moss) which was also at par with $\mathrm{T}_{7}, \mathrm{~T}_{3}$, and $\mathrm{T}_{2}$. Similarly, the minimum shoot length $(4 \mathrm{~cm})$ and seedling length $(4 \mathrm{~cm})$ was observed in $\mathrm{T}_{9}$. The treatment $\mathrm{T}_{12}$ (Peat moss) has shown its maximum efficiency to improve the shoot and seedling length within forty five days of sowing as compared to the rest of the treatment (Figure 4 - Figure 6). Peat moss as a growing medium is widely used for production of selected crops in the tropics [17,18]. Yahya et al. [17] reported that peat moss improved the shoot and seedling length of rough lemon (Citrus jambhiri L.). Good physical properties e.g. low shrinkage, high water content and low bulk density improve the overall growth of vegetables as well as fruit nurseries $[19,20]$. In the case of the effectiveness of growth media on root length, not much significant difference was observed between treatments mean root length per plant (Figure 4). Among all treatments, the maximum $(6.4 \mathrm{~cm})$ increase in root length was observed in treatment $T_{6}(1$ part bhaggas +1 part peat moss) which were also at par with $\mathrm{T}_{12}, \mathrm{~T}_{6}$, and $\mathrm{T}_{3}$. The minimum effect of growth media on root length was $(0.9$ $\mathrm{cm}$ ) observed in treatment $T_{9}$ (Soil). It showed that the behavior treatment $T_{6}$ is similar to treatment $T_{12}$ to improve proliferation and root length of seedlings. The main reason is that the media composition of treatment $\mathrm{T}_{6}$ and $\mathrm{T}_{12}$ near close to each other. As already discussed peat moss provide good medium for seed germination. Good physical properties of peat moss. 


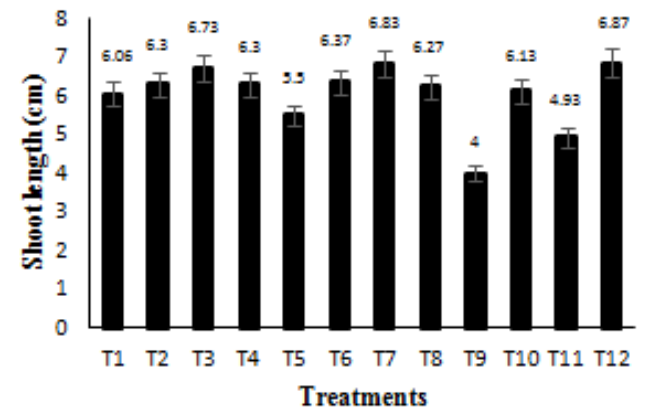

Figure 3: Effect growth media on shoot length (cm).

Significant differences are at $\mathrm{P}<0.05$.

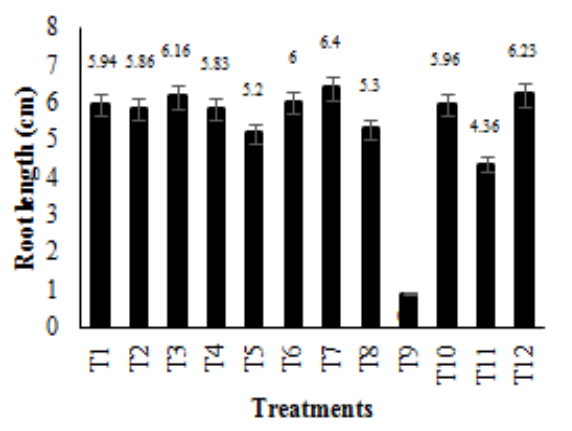

Figure 4: Effect growth media on root length $(\mathrm{cm})$.

Significant differences are at $\mathrm{P}<0.05$.

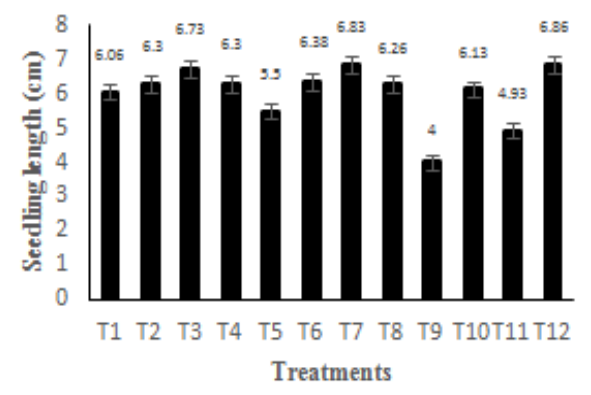

Figure 5: Effect growth media on seedling length $(\mathrm{cm})$.

Significant differences are at $\mathrm{P}<0.05$.

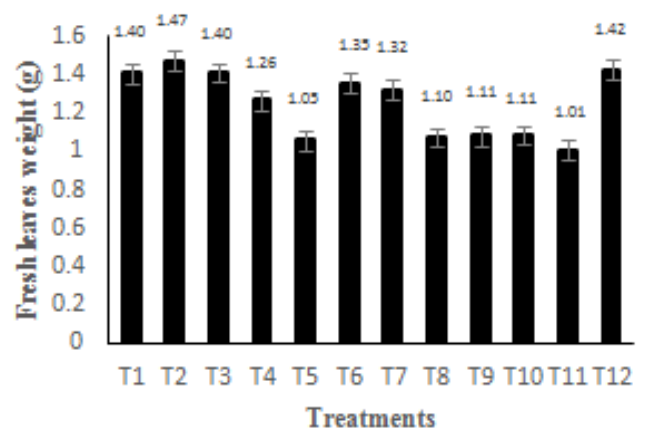

Figure 6: Effect growth media on fresh leaves weight (gm). Significant differences are at $\mathrm{P}<0.05$.
Likewise, the length of seedling parameters affected by the composition of growth media, fresh weight of seedling parameters was also influenced by the composition of growth media. Treatment $\mathrm{T}_{10}$ (Coco-coir) behaves similar to the fresh weight of root and shoot (figure $7 \&$ figure 8). The maximum fresh weight $(1.8277 \mathrm{~g})$ and $(1.57 \mathrm{~g})$ was recorded in treatment $\mathrm{T}_{10}$ (Coco-coir) respectively for root length and shoot length. But the behavior of fresh leaves weight was different as compared to the treatment $T_{10}$ and the maximum fresh leaves weight was noted in treatment $T_{2}$ (1 part peat moss +1 part compost) as compared to $T_{10}$ or rest of other treatment. However, the minimum behavior of fresh weight for root, shoot and leaves (1.0633 $\mathrm{g}),(1.0923 \mathrm{~g})$ and $(1.0576 \mathrm{~g})$ respectively was noted in the same treatment $\mathrm{T}_{2}(1$ part peat moss +1 part compost.

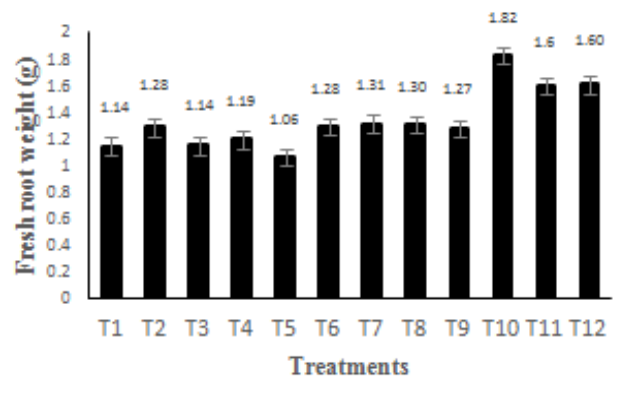

Figure 7: Effect growth media on fresh root weight (gm). Significant differences are at $\mathrm{P}<0.05$.

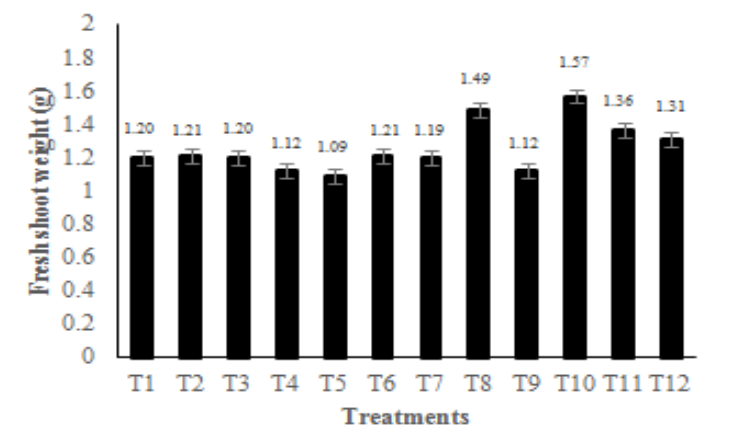

Figure 8: Effect growth media on fresh shoot weight (gm). Significant differences are at $\mathrm{P}<0.05$.

Similarly, the fresh weight and dry weight of different seedling were significantly influenced by the treatment $T_{5}$ as compared to the other treatments (figure $9 \&$ figure 10 ). The maximum dry root weight $(0.0884 \mathrm{~g})$ and dry shoot 
weight $(0.084 \mathrm{~g})$ of seedling were recorded in the same treatment $\mathrm{T}_{5}$ (1 part bhaggas +1 peat soil) but a maximum dry weight of leaves $(0.1181 \mathrm{~g})$ observed in treatment $\mathrm{T}_{3}$ (1 part compost +1 part coco-coir). Similarly, the minimum dry leaves and shoot dry weight was found $(0.0671 \mathrm{~g})$ and $(0.0422 \mathrm{~g})$ in treatment $\mathrm{T}_{11}$ (Compost) but case of dry root weight as observed in treatment $\mathrm{T}_{8}$ (Bhaggas).

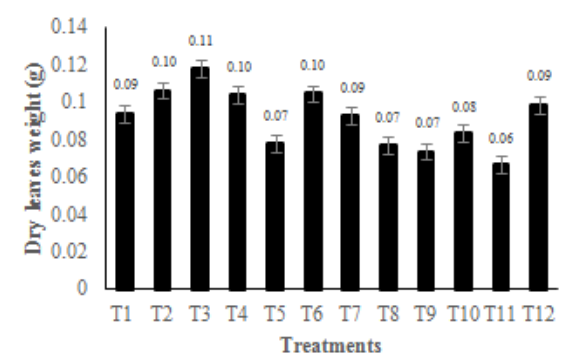

Figure 9: Effect growth media on dry leaves weight (gm). Significant differences are at $\mathrm{P}<0.05$.

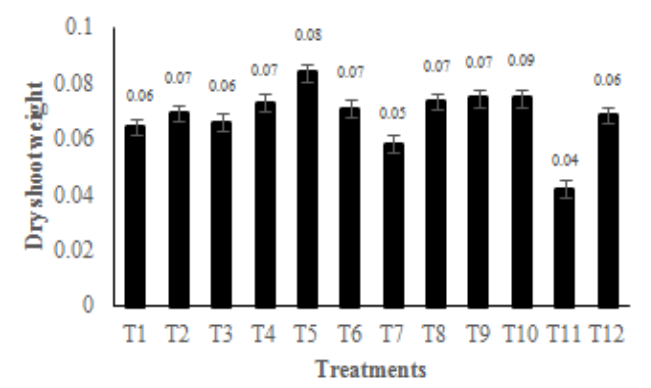

Figure 10: Effect growth media on dry shoot weight (gm). Significant differences are at $\mathrm{P}<0.05$.

Maximum dry matter content of leaves (6.6322g) was observed in $\mathrm{T}_{11}$ (Compost) but in case of root and shoot mater contents, the maximum was recorded in treatment $\mathrm{T}_{5}$. Significant differences were observed between treatment mean dry matter content per plant (Figure 9 Figure 12) Minimum dry matter content of leaves (6.6322g) and shoot (3.203) was observed in $\mathrm{T}_{11}$ (Compost) and in case of root, the minimum dry root matter contents $(3.3967 \mathrm{~g})$ were recorded in treatment $\mathrm{T}_{2}$.

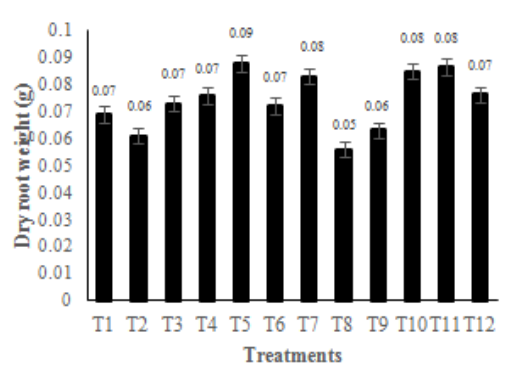

Figure 11: Effect growth media on dry root weight (gm). Significant differences are at $\mathrm{P}<0.05$.

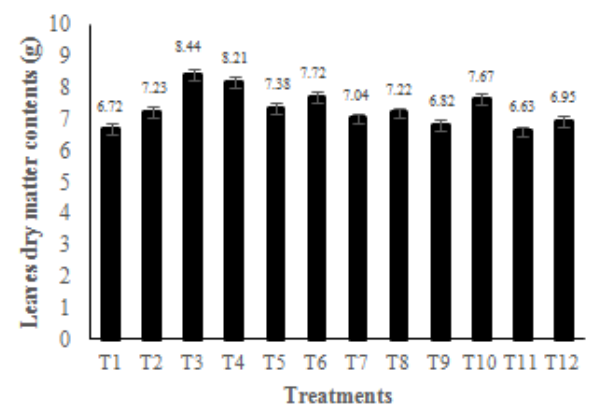

Figure 12: Effect growth media on dry weight (gm). Significant differences are at $\mathrm{P}<0.05$.

Plant species need for water and nutrients varies considerably. Therefore, there is a need of different types of growing media for the provision of best growing conditions [21].

\section{CONCLUSION}

Peat moss was the most efficient among all the other growing media for producing the maximum number of leaves, shoot length, root length and seedling length while, compost was found to be a most effective medium for maximum seed germination.

\section{REFERENCES}

1. Statistics (2015-2016) Ministry of food, agriculture \& livestock. Fruit, vegetables and condiments statistics of Pakistan, Government of Pakistan.

2. Altaf N (2006) Embryogenesis in undeveloped ovules of citrus cultivars in response to gamma radiation. Pakistan Journal of Botany 38(3): 589-595. 
http://www.tridhascholars.org | June-2020

3. Nasir MA, Makon MNK, Khan AUR, et al. (2011) Effect of different rootstocks on vegetative growth and canopy of Kinnow Mandarin plants. Indian Journal of Agricultural Research 49(1): 65-71.

4. Anonymous (2002) Ministry of Food, Agriculture \& Livestock. Fruit, vegetables and condiments statistics of Pakistan, Government of Pakistan.

5. Abad M, Noguera P, Puchades R, et al. (2002) Physico-chemical and chemical properties of some coconut coir dusts for use as a peat substitute for containerised ornamental plants. Bioresource Technology 82(3): 241-245.

6. Wilson SB, Stoffella PJ, Graetz DA (2002) Development of compost-based media for containerized perennials. Scientia Horticulturae 93(3-4): 311-320.

7. Agbo CU, Omaliko CM (2006) Initiation and growth of shoots of Gongronema latifolia Benth stem cuttings in different rooting media. African Journal of Biotechnology 5(5): 425-428.

8. Baiyeri KP, Mbah BN (2006) Effects of soilless and soil-based nursery media on seedling emergence, growth and response to water stress of African breadfruit (Treculia africana Decne). African Journal of Biotechnology 5(15).

9. Bachman GR, Metzger JD (2007) Physical and chemical characteristics of a commercial potting substrate amended with vermicompost produced from two different manure sources. HortTechnology 17(3): 336-340.

10. Ahmad I, Khan MA, Qasim M, et al. (2012) Substrates effects on growth, yield and quality of Rosa hybrida L. Pakistan Journal of Botany 44(1): 177-185.

11. Sterrett SB (2001) Compost as Horticultural Substrates for Vegetable Transplant Production. In: Compost Utilization in Horticultural Crooping Systems, StoVella PJ and Kahn BA (Eds.). Lewis Publication, Boca Raton, FL: $227-240$.

12. Bustamante MA, Paredes C, Moral R, et al. (2008) Composts from distillery wastes as peat substitutes for transplant production. Resources, Conservation and Recycling 52(5): 792-799.

13. Abad M, Noguera P, Bures S (2001) National inventory of organic wastes for use as growing media for ornamental potted plant production: Case study in Spain. Bioresource Technology 77(2): 197-200.

14. Maher M, Prasad M, Raviv M (2008) Organic soilless media components. In: Soilless culture: Theory and practice Raviv $\mathrm{M}$ and Lieth JH (Eds.), Elsevier, London, UK: 459-504.

15. Usman M, Samad WA, Fatima B, et al. (2013) Pollen parent enhances fruit size and quality in intervarietal crosses in guava (Psidium guajava). International Journal of Agriculture and Biology 15(1): 125-129.

16. Wilson SB, Stoffella PJ, Graetz DA (2001) Use of compost as a media amendment for containerized production of two subtropical perennials. Journal of Environmental Horticulture 19(1): 37-42.

17. Yahaya A, Safie H, Mohklas MS (1999) Growth and flowering responses of potted chrysanthemum in a coir dust-based medium to different rates of slow released fertilizer. Journal of Tropical Agriculture and Food Science 27: 39-46.

18. Treder J (2008) The effects of cocopeat and fertilization on the growth and flowering of oriental lily 'star gazer'. Journal of Fruit and Ornamental Plant Research 16: 361-370.

19. Sahin U, Ors S, Ercisli S, et al. (2005) Effect of pumice amendment on physical soil properties and strawberry plant growth. Journal of Central European Agriculture 6(3): 361-366.

20. Riaz A, Arshad M, Younis A, et al. (2008) Effects of different growing media on growth and flowering of Zinnia elegans cv. Blue point. Pakistan Journal of Botany 40(4): 1579-1585.

21. Abirami K, Rema J, Mathew PA, et al. (2010) Effect of different propagation media on seed germination, seedling growth and vigour of nutmeg (Myristica fragrans Houtt.). Journal of Medicinal Plants Research 4(19): 2054- 2058. 